Bangladesh J. Plant Taxon. 14(2): 129-145, 2007 (December)

\title{
ETHNOBOTANICAL INVESTIGATION INTO THE MANDI ETHNIC COMMUNITY IN BANGLADESH
}

\author{
Pavel Partha $^{1}$ and A.B.M. Enayet Hossain ${ }^{2}$ \\ Bangladesh Resource Centre for Indigenous Knowledge (BARCIK) \\ House 50, Road 16 (new), Dhanmondi, Dhaka 1209, Bangladesh
}

Key words: Ethnobotany, Ethnic community, Mandi, Bangladesh

\begin{abstract}
The present ethnobotanical investigation has been carried out into the Mandi ethnic communities of 32 villages of seven upazillas of Dhaka and Sylhet Divisions in Bangladesh. A total of 109 plant species belonging to 59 plant families were found to be used by the communities to treat 38 common human diseases, in ethnoveterinary practices, for pest control, as food, and also to perform rituals, taboos and hunting.
\end{abstract}

\section{Introduction}

In the present world, traditional botanical knowledge and ethnobotanical research are playing an important role in biological investigation, economy and practical uses. In addition, this knowledge and experience of different ethnic groups can play a vital role in the identification, conservation and use of various plant resources including the wild and uncultivated. In Bangladesh, there are many marginalized ethnic communities of different lifestyle and culture. They use surrounding plants for their primary healthcare along with other necessities, which are based on their traditional knowledge and dynamic cultural heritage.

Preliminary work of Hassan and Khan (1986) in ethnobotanical research is regarded as pioneer endeavour in Bangladesh. Since then, Mia and Huq (1988), Alam (1992), Alam et al. (1996), Uddin et al. (2001), Khan et al. (2002), Partha (2002), Partha and Hossain (2002) and Yusuf et al. (2006) have also made significant contribution to our understanding of enthnobotany in Bangladesh. Most of these studies, however, focused on tribal communities in the Chittagong Hill Tracts with some surveys on the tribes in the Sylhet region.

An initial survey was conducted by Khan (1998) on Mandi (Garo) tribe inhabiting Madhupur and Haluaghat in the districts of Tangail and Mymensingh, respectively. In the nearby Indian State of Meghalaya, Rao (1981) documented the medicinal plants used by the Khasi and Garo communities. Rao and Shampru (1997) later on listed 78 plant species used by Garos of Meghalaya for food (30), medicine (24), fish poison (5), fiber (6), dye (3), miscellaneous (10) and from magico-religious beliefs.

${ }^{1}$ Corresponding author. E-mail: animistbangla@yahoo.com ${ }^{2}$ Department of Botany, Jahangirnagar University, Savar, Dhaka 1342, Bangladesh. 
Our current understanding of the enthnobotany of Mandi community of Bangladesh is very limited. The present investigation, therefore, gives an opportunity to explore the inter-relationships between plants, human beings, environment, ecology and traditional knowledge and culture of the Mandi ethnic community in 32 villages of two divisions in central-north and north-eastern Bangladesh.

\section{Materials and Methods}

Mandi ethnic community: Mandi is the largest marginalized ethnic community in the Dhaka Division of Bangladesh. Total Mandi population in Bangladesh is about 64,280 (Bangladesh Population Census of 1991). Mandis are generally known as 'Garo', but they call themselves 'Mandi'. In their 'A 'tchik' dialect 'Mandi' means 'human being'.

Study area: The present investigation was carried out between December 2000 and May 2002 into the Mandi ethnic communities of 32 different villages of Sunamganj Sadar and Tahirpur Upazillas (Sunamganj District) of Sylhet Division; and Durgapur and Kalmakanda Upazillas (Netrokona District), Nalitabari Upazilla (Sherpur District), Haluaghat and Dhubaura Upazillas (Mymensingh District) and Madhupur Upazilla (Tangail District) of Dhaka Division.

Information collection: The ethnobotanical information was collected by 'participant observations', from focus group discussions, and interviewing local people and local medicine men who prescribe their own herbal preparations.

For ethnobotanical research, 'participant observation' is given more preference. For this participant observation, a researcher has to live with the ethnic people for a long time. But owing to limited scope and allocated time for the present ethnobotanical survey, the first author could only spend few trips to the specified areas and stay for a short while with the informants. However, the present endeavour was initiated far back in 1997 through repeated visits to various ethnic areas and making friendship with the ethnic communities. Although visits had been made since 1997, much time was spent from December 2000 to May 2002 for the present ethnobotanical investigation reported in this communication. In their every social and cultural activities and festivals, both physical and mental participation was made during the period of the survey.

The first author also participated in their 'jhumming' (shifting cultivation) and other household works. The women were also interviewed at the time of cooking and collecting vegetables and fruits from the 'jhum-jungle', and the information and processes were documented.

The ethnic medicine men were interviewed individually in the forests where they pointed out the herbs that they use to cure different ailments. Information was also gathered from the medicine men using two separate questionnaires. 
Plant material collection: A large number of plant materials were collected during the present survey and were preserved as herbarium sheets. During plant collection and making herbarium specimens, unknown, little known and important plants were given more preference. All the herbarium specimens are preserved in the Jahangirnagar University Herbarium (JUH), Department of Botany, Jahangirnagar University, Savar, Dhaka 1342. The JUH allows anybody to use these specimens for academic and research purposes.

\section{Results and Discussion}

The plant species documented in the present survey are enumerated in the Table 1 in alphabetic order of their scientific names. These are accompanied by their local names in Mandi language, localities (village and district) and ethnobotanic uses. The medicinal uses of plants listed here are indicative and are not accompanied by doses, therefore the readers are not encouraged to follow them without verification.

Most of the Mandi people rely upon surrounding plant wealth for their health-care, food and other life accessories. Present ethnobotanical investigation generated important information that might be useful for health-care programme, economic and agricultural policy development, alternative food programme, development of essential drugs, and biodiversity conservation action plan for Bangladesh. Since limited work has been done in the field of ethnobotanical research in Bangladesh, information of Mandi botanical knowledge documented in this paper is almost new at academic ethnobotanical paradigm. Some specific suggestions are articulated as below.

- Before entering into 'new technology' and 'modern medicine', ethnobotanical and traditional knowledge of all ethnic groups of Bangladesh are to be documented with a proper `Free Prior Informed Consent’ way.

- The land and natural resource rights of the ethnic people are to be ensured. Antiethnic, anti-ecological development processes like large dams, eco-park or any other infrastructural developments should not be undertaken, which destroy life, livelihoods, resources and ethnobotanical practices.

- Ethnic people's traditional knowledge and culture is to be conserved with active help of proper policy framework. Eco-friendly policy and laws are to be formulated for conservation of medicinal and economic plant species. Successful enactment of the draft 'Biodiversity and Community Knowledge Protection Act, 1998' could be a good example in this regard. 
Table 1. Plants used by the Mandi ethnic communities of Dhaka and Sylhet Divisions.

\begin{tabular}{|c|c|c|c|c|c|}
\hline $\begin{array}{l}\text { Sl. } \\
\text { No. }\end{array}$ & Scientific name & Family & Mandi name & $\begin{array}{l}\text { Location } \\
\text { (Village, District) }\end{array}$ & Use \\
\hline 1. & Abutilon indicum (L.) Sweet. & Malvaceae & Ha-nijang-zalek & $\begin{array}{l}\text { Thanarbaid, } \\
\text { Tangail }\end{array}$ & Leaf and root paste is used for migraine pain. \\
\hline 2. & Achyranthes aspera L. & Amaranthaceae & Mimang-khachi & $\begin{array}{l}\text { Menkifanda, } \\
\text { Netrokona }\end{array}$ & $\begin{array}{l}\text { Root juice is used treating worms and } \\
\text { inflammation in urinary tract. }\end{array}$ \\
\hline 3. & Acorus calamus L. & Araceae & Phachi, Chisik & $\begin{array}{l}\text { Sagordighi, } \\
\text { Netrokona }\end{array}$ & $\begin{array}{l}\text { Leaf juice is used for children in "Baw-batasi" } \\
\text { (any physical change caused by evil spirits) } \\
\text { disease. }\end{array}$ \\
\hline 4. & Adhatoda vasica Nees & Acanthaceae & Alok-bizak & $\begin{array}{l}\text { Narayantala, } \\
\text { Sunamganj }\end{array}$ & Decoction of twig is used in cough and cold. \\
\hline 5. & Agaricus campestris L. & Agaricaceae & Na-phang & $\begin{array}{l}\text { Sagordighi, } \\
\text { Netrokona }\end{array}$ & $\begin{array}{l}\text { Plant juice and edible mushroom are used to cure } \\
\text { menstruation problem. }\end{array}$ \\
\hline 6. & $\begin{array}{l}\text { Aloe vera L. (Syn. A. } \\
\text { barbadensis Mill.) }\end{array}$ & Liliaceae & Dip-thi-kanchon & $\begin{array}{l}\text { Ranikhong, } \\
\text { Netrokona }\end{array}$ & $\begin{array}{l}\text { Leaves are cut into small pieces and soaked in } \\
\text { water, the extract mixed with sugar is used for } \\
\text { liver complications and to remove tiredness. }\end{array}$ \\
\hline 7. & Amaranthus spinosus L. & Amaranthaceae & $\begin{array}{l}\text { Kuriakanta, } \\
\text { Kulelhara }\end{array}$ & $\begin{array}{l}\text { Farongpara \& } \\
\text { Menkifanda, } \\
\text { Netrokona }\end{array}$ & $\begin{array}{l}\text { Slightly warm root paste is applied locally on } \\
\text { boils. Whole plant paste is used as ointment for } \\
\text { rheumatic pain. See also Benincasa hispida. }\end{array}$ \\
\hline 8. & $\begin{array}{l}\text { Amorphophallus bulbifer (Roxb.) } \\
\text { Bl. }\end{array}$ & Araceae & $\begin{array}{l}\text { Chung-muru, } \\
\text { Baghadumm }\end{array}$ & $\begin{array}{l}\text { Ranikhong, } \\
\text { Netrokona }\end{array}$ & Used as vegetables. \\
\hline 9. & Andrographis paniculata Nees & Acanthaceae & Gumkhah-sum & $\begin{array}{l}\text { Hagurakuri, } \\
\text { Tangail }\end{array}$ & Leaf juice is used for fever and pain. \\
\hline 10. & Aristolochia indica L. & Aristolochiaceae & Chong-khengsum & $\begin{array}{l}\text { Thanarbaid, } \\
\text { Tangail }\end{array}$ & $\begin{array}{l}\text { Leaf and tuber paste is used as ointment in } \\
\text { burning. }\end{array}$ \\
\hline
\end{tabular}




\section{Table 1. (Contd.)}

\begin{tabular}{|c|c|c|c|c|c|}
\hline $\begin{array}{l}\text { Sl. } \\
\text { No. }\end{array}$ & Scientific name & Family & Mandi name & $\begin{array}{l}\text { Location } \\
\text { (Village, District) }\end{array}$ & Use \\
\hline 11. & $\begin{array}{l}\text { Artemisia nilagirica (Clarke) } \\
\text { Pamp }\end{array}$ & Asteraceae & $\begin{array}{l}\text { Nagdewna, } \\
\text { Ramanisam }\end{array}$ & $\begin{array}{l}\text { Sagordighi, } \\
\text { Netrokona; } \\
\text { Chonia, Tangail }\end{array}$ & $\begin{array}{l}\text { Leaf juice is used to treat leprosy. Young twig is } \\
\text { used in preparation of fermenting medium } \\
\text { "Chumanti" for traditional liquor "Chu". Fresh } \\
\text { leaf juice is used for liver pain and dysentery. }\end{array}$ \\
\hline 12. & Artocarpus heterophyllus Lamk. & Moraceae & Thibrong & $\begin{array}{l}\text { Sagordighi, } \\
\text { Netrokona; } \\
\text { Chonia, Tangail }\end{array}$ & $\begin{array}{l}\text { Stem gall is tied to the affected testis to prevent } \\
\text { hernia. Timber is used for "K'ma/Khima" } \\
\text { (monument for dead person). }\end{array}$ \\
\hline 13. & $\begin{array}{l}\text { Asparagus recemosus L. (Syn. A. } \\
\text { officinalis L.) }\end{array}$ & Liliaceae & $\begin{array}{l}\text { Mimang- } \\
\text { thamachii }\end{array}$ & Chonia, Tangail & Root juice is used to increase sperm count. \\
\hline 14. & $\begin{array}{l}\text { Bambusa longispiculata Gamble } \\
\text { ex Brandis }\end{array}$ & Poaceae & Tolah-wah & Chonia, Tangail & $\begin{array}{l}\text { Used for making the socio-religious musical } \\
\text { instrument "Alongma", "Bangsi" and "Adori". }\end{array}$ \\
\hline 15. & $\begin{array}{l}\text { Basella alba L. (Syn. B. rubra } \\
\text { L.) }\end{array}$ & Basellaceae & Puisak & $\begin{array}{l}\text { Sagordighi, } \\
\text { Netrokona }\end{array}$ & $\begin{array}{l}\text { Leaf and stem paste is used for headache. See } \\
\text { also Benincasa hispida. }\end{array}$ \\
\hline 16. & Bauhinia vahlii W. et A. & Caesalpiniaceae & $\begin{array}{l}\text { Lota-kanchan- } \\
\text { phang }\end{array}$ & Khazai, Tangail & Fruits are eaten raw or roasted when mature. \\
\hline 17. & $\begin{array}{l}\text { Benincasa hispida (Thunb.) } \\
\text { Cogn. }\end{array}$ & Cucurbitaceae & Ak-kharu & $\begin{array}{l}\text { Sagordighi, } \\
\text { Netrokona }\end{array}$ & $\begin{array}{l}\text { Paste made of "Ak-kharu" seed, Basella alba leaf, } \\
\text { Amaranthus spinosus root and garlic is used to } \\
\text { treat "Jal-batasi" (after pregnancy, excess } \\
\text { secretion of menstruation blood) disease in } \\
\text { women. See also Physalis minima. }\end{array}$ \\
\hline 18. & Bixa orellana $\mathrm{L}$ & Bixaceae & Ronjak-phang & $\begin{array}{l}\text { Boheratoli, } \\
\text { Netrokona }\end{array}$ & Seeds are used to make red dye. \\
\hline 19. & $\begin{array}{l}\text { Bombax ceiba L. (Syn. Salmalia } \\
\text { malabarica (DC.) Sch. \& Endle.) }\end{array}$ & Bombacaceae & Man-chow & $\begin{array}{l}\text { Bhabanipur } \\
\text { (North), } \\
\text { Netrokona }\end{array}$ & $\begin{array}{l}\text { The religious worship "Asong-meddi" is only } \\
\text { performed under this tree for preventing pox and } \\
\text { cholera. }\end{array}$ \\
\hline
\end{tabular}


Table 1. (Contd.)

\begin{tabular}{|c|c|c|c|c|c|}
\hline $\begin{array}{l}\text { Sl. } \\
\text { No. }\end{array}$ & Scientific name & Family & Mandi name & $\begin{array}{l}\text { Location } \\
\text { (Village, District) }\end{array}$ & Use \\
\hline 20. & Borassus flabellifer L. & Arecaceae & Tal-phang & $\begin{array}{l}\text { Telungia \& } \\
\text { Utrail, } \\
\text { Netrokona }\end{array}$ & $\begin{array}{l}\text { Fresh flower paste is used to relieve the } \\
\text { inflammation of breast. Leaves are used in the } \\
\text { religious worship "Jolkuri-Meddi". }\end{array}$ \\
\hline 21. & Bridelia retusa Spreng & Euphorbiaceae & Heja & Chonia, Tangail & Ripe fruits are edible. \\
\hline 22. & $\begin{array}{l}\text { Bryophyllum pinnata (Lamk.) } \\
\text { Pers. (Syn. Bryophyllum } \\
\text { calycinum Salisb.) }\end{array}$ & Crassulaceae & Samjangi & $\begin{array}{l}\text { Sagordighi, } \\
\text { Netrokona }\end{array}$ & $\begin{array}{l}\text { Leaves are wrapped with banana leaf and put in } \\
\text { hot ashes until it becomes soft and half-boiled. } \\
\text { Then it is squeezed to extract the juice to use for } \\
\text { dysentery and improving sexual strength. }\end{array}$ \\
\hline 23. & $\begin{array}{l}\text { Cajanus cajan (L.) Millsp. (Syn. } \\
\text { C. indicus Spreng.) }\end{array}$ & Papilionaceae & Mendu & $\begin{array}{l}\text { Utrail, } \\
\text { Netrokona }\end{array}$ & $\begin{array}{l}\text { Fresh leaf juice is mixed with sugar and is used in } \\
\text { jaundice. }\end{array}$ \\
\hline 24. & Canna indica L. var. speciosa & Cannaceae & Diggi-walsun & $\begin{array}{l}\text { Sagordighi, } \\
\text { Netrokona }\end{array}$ & $\begin{array}{l}\text { Paste made of tuber of "Diggi-walsun" and fruit } \\
\text { ash of "Bhoittyakola" (Musa sapientum L. var. } \\
\text { sylvestris) is used in excess menstruation. }\end{array}$ \\
\hline 25. & Cardiospermum halicacabum L. & Sapindaceae & $\begin{array}{l}\text { Gondoli, } \\
\text { Sithapu }\end{array}$ & $\begin{array}{l}\text { Menkifanda, } \\
\text { Netrokona; } \\
\text { Gaira, Tangail }\end{array}$ & $\begin{array}{l}\text { Young twig juice is applied locally on eyes to } \\
\text { prevent inflammation of eyes. Green fruits are } \\
\text { edible. Root paste is used for dyspepsia of cattle. }\end{array}$ \\
\hline 26. & Careya arborea Roxb. & Lecythidaceae & Dombel & $\begin{array}{l}\text { Thanarbaid, } \\
\text { Tangail }\end{array}$ & Decoction of stem-bark is used as red dye. \\
\hline 27. & Caryota urens (L.) Kirt & Arecaceae & Souii-phang & $\begin{array}{l}\text { Baragup, } \\
\text { Sunamganj }\end{array}$ & $\begin{array}{l}\text { Sun-dried seeds are used as a substitute for Areca } \\
\text { catechu and used with betel leaf as a chewing } \\
\text { material. }\end{array}$ \\
\hline 28. & Celosia cristata L. & Amaranthaceae & Shibjota & $\begin{array}{l}\text { Monikura, } \\
\text { Mymensingh }\end{array}$ & $\begin{array}{l}\text { Young leave is cooked with small fish and is used } \\
\text { for excess menstruation. }\end{array}$ \\
\hline
\end{tabular}




\section{Table 1. (Contd.)}

\begin{tabular}{|c|c|c|c|c|c|}
\hline $\begin{array}{l}\text { Sl. } \\
\text { No. }\end{array}$ & Scientific name & Family & Mandi name & $\begin{array}{l}\text { Location } \\
\text { (Village, District) }\end{array}$ & Use \\
\hline 29. & Centella asiatica (L.) Urban. & Apiaceae & $\begin{array}{l}\text { Misi-nachil, } \\
\text { Thorkuri }\end{array}$ & $\begin{array}{l}\text { Menkifanda, } \\
\text { Netrokona; } \\
\text { Kakorkandi, } \\
\text { Sherpur }\end{array}$ & $\begin{array}{l}\text { Leaf paste is used for rheumatic pain. Paste made } \\
\text { of leaves of "Misi-nachil" and "Jhinga" (Luffa } \\
\text { acutangula) seeds is used internally for dog bites. } \\
\text { Roasted leaf juice is used in jaundice. }\end{array}$ \\
\hline 30. & $\begin{array}{l}\text { Chrysopogon aciculatus (Retz.) } \\
\text { Trin. (Syn. Andropogon } \\
\text { aciculatus Retz.) }\end{array}$ & Poaceae & Nengra-bon & $\begin{array}{l}\text { Lengoora \& } \\
\text { Menkifanda, } \\
\text { Netrokona }\end{array}$ & $\begin{array}{l}\text { Root juice is used in liver pain. Inflorescence } \\
\text { paste is applied on scabies after slight scrapping. }\end{array}$ \\
\hline 31. & $\begin{array}{l}\text { Cinnamomum tamala (Buch.- } \\
\text { Ham.) Nees \& Eberm. }\end{array}$ & Lauraceae & Tejpata & $\begin{array}{l}\text { Sagordighi, } \\
\text { Netrokona }\end{array}$ & $\begin{array}{l}\text { Juice made of fresh young leaf of "Tejpata" and } \\
\text { whole plant of "Sarnalot" (Cuscuta reflexa) is } \\
\text { used to treat jaundice. }\end{array}$ \\
\hline 32. & $\begin{array}{l}\text { Cissus quandrangularis L. (Syn. } \\
\text { Vitts quadrangularis) }\end{array}$ & Vitaceae & $\begin{array}{l}\text { Moi-bhanga lot, } \\
\text { Diggi-therengi }\end{array}$ & $\begin{array}{l}\text { Berui, } \\
\text { Mymensingh }\end{array}$ & $\begin{array}{l}\text { Plant paste is used in the treatment of fractured } \\
\text { bones. }\end{array}$ \\
\hline 33. & $\begin{array}{l}\text { Cleistocalyx operaculatus } \\
\text { (Roxb.) Merr. \& Perry. (Syn. } \\
\text { Eugenia operculata Roxb.) }\end{array}$ & Myrtaceae & Bol-rujol-phang & Chonia, Tangail & Ripe fruits are edible. \\
\hline 34. & Clerodendrum viscosum Vent. & Verbenaceae & $\begin{array}{l}\text { Samkhu-khuku- } \\
\text { phang, } \\
\text { Samakhsi }\end{array}$ & $\begin{array}{l}\text { Baromari, } \\
\text { Sherpur; } \\
\text { Thanarbaid, } \\
\text { Tangail }\end{array}$ & $\begin{array}{l}\text { Young twig is used in preparation of fermenting } \\
\text { medium "Chumanti" for traditional liquor "Chu". } \\
\text { Young leaf juice is mixed with sugar and used for } \\
\text { ascaris and liver pain. }\end{array}$ \\
\hline 35. & Coix lachryma-jobi L. & Poaceae & Riksiri, Simpuli & $\begin{array}{l}\text { Sagordighi, } \\
\text { Netrokona; } \\
\text { Thanarbaid, } \\
\text { Tangail }\end{array}$ & $\begin{array}{l}\text { Root paste is used for treating leprosy. Paste } \\
\text { made of "Riksiri" tuber, "Tulsi phang" (Ocimum } \\
\text { sanctum) leaf, and "Belathiphang" (Aegle } \\
\text { marmelos) leaf is used as female oral } \\
\text { contraceptive after menstruation. }\end{array}$ \\
\hline 36. & Commelina benghalensis L. & Commelinaceae & $\begin{array}{l}\text { Ankhi-zachi, } \\
\text { Hanki-zachi }\end{array}$ & Chonia, Tangail & $\begin{array}{l}\text { Whole plant juice is used for children's late- } \\
\text { walking. }\end{array}$ \\
\hline
\end{tabular}




\section{Table 1. (Contd.)}

\begin{tabular}{|c|c|c|c|c|c|}
\hline $\begin{array}{l}\text { Sl. } \\
\text { No. }\end{array}$ & Scientific name & Family & Mandi name & $\begin{array}{l}\text { Location } \\
\text { (Village, District) }\end{array}$ & Use \\
\hline 37. & Crinum defixum Ker. & Amaryllidaceae & $\begin{array}{l}\text { Dukkhanu- } \\
\text { sheng }\end{array}$ & Gaira, Tangail & $\begin{array}{l}\text { Tuber paste is mixed with table salt and is used } \\
\text { for flatulence of cattle. }\end{array}$ \\
\hline 38. & Curcuma amada Roxb. & Zingiberaceae & $\begin{array}{l}\text { Diggi, Diggi- } \\
\text { thegacu }\end{array}$ & $\begin{array}{l}\text { Ranikhong \& } \\
\text { Sagordighi, } \\
\text { Netrokona }\end{array}$ & $\begin{array}{l}\text { Tuber paste is used against evil spirits. Root juice } \\
\text { is used to treat impotency. }\end{array}$ \\
\hline 39. & Curcuma caesia Roxb. & Zingiberaceae & Sammi-seng & $\begin{array}{l}\text { Chonia \& } \\
\text { Pirgacha, } \\
\text { Tangail }\end{array}$ & $\begin{array}{l}\text { Fresh tuber juice is used as an antidote after } \\
\text { poisoning. Tuber paste is used for liver pain. }\end{array}$ \\
\hline 40. & $\begin{array}{l}\text { Dendrophthoe falcata (L. f.) } \\
\text { Etting. (Syn. Loranthus } \\
\text { longiflorus Desr.) }\end{array}$ & Loranthaceae & Dorangsi-phang & $\begin{array}{l}\text { Sagordighi, } \\
\text { Netrokona }\end{array}$ & $\begin{array}{l}\text { Leaf paste is mixed with ginger (Zingiber } \\
\text { officinale) and used to treat fractured bones. }\end{array}$ \\
\hline 41. & Dillenia indica L. & Dilleniaceae & Thigi & $\begin{array}{l}\text { Valukapara, } \\
\text { Mymensingh }\end{array}$ & $\begin{array}{l}\text { Decoction of fruit mixed with table salt is used } \\
\text { for dyspepsia of domestic pig. }\end{array}$ \\
\hline 42. & Dioscorea alata L. var. globosa & Dioscoreaceae & Tha-mandi & $\begin{array}{l}\text { Madhupur, } \\
\text { Tangail }\end{array}$ & $\begin{array}{l}\text { One of the main homestead crops of Mandi in } \\
\text { Madhupur sal (Shorea robusta) forest areas. } \\
\text { Tuber and bulbil of this plant used in the main } \\
\text { jhum festival 'wann.a (wangala)'. }\end{array}$ \\
\hline 43. & Dioscorea sp. & Dioscoreaceae & Tha-ak & $\begin{array}{l}\text { Sainnamari \& } \\
\text { Thanarbaid, } \\
\text { Tangail }\end{array}$ & Tuber paste is used as poison in hunting. \\
\hline 44. & $\begin{array}{l}\text { Drynaria quercifolia (L.) J. } \\
\text { Smith }\end{array}$ & Polypodiaceae & Doreng-jasi & $\begin{array}{l}\text { Monsapara, } \\
\text { Mymensingh }\end{array}$ & $\begin{array}{l}\text { Rhizome paste is used to protect children from } \\
\text { evil spirit. }\end{array}$ \\
\hline 45. & Elentherine plicata Hub & Liliaceae & Chinisum & $\begin{array}{l}\text { Pirgacha, } \\
\text { Tangail }\end{array}$ & Bulb paste is used for dysentery and liver pain. \\
\hline 46. & Eleusine indica (L.) Gaerten & Poaceae & $\begin{array}{l}\text { Gang-ring- } \\
\text { phang }\end{array}$ & $\begin{array}{l}\text { Sagordighi, } \\
\text { Netrokona }\end{array}$ & Whole plant juice is used in wounds and cuts. \\
\hline
\end{tabular}




\section{Table 1. (Contd.)}

\begin{tabular}{|c|c|c|c|c|c|}
\hline $\begin{array}{l}\text { Sl. } \\
\text { No. }\end{array}$ & Scientific name & Family & Mandi name & $\begin{array}{l}\text { Location } \\
\text { (Village, District) }\end{array}$ & Use \\
\hline 47. & Erythrina variegata $\mathrm{L}$. & Papilionaceae & $\begin{array}{l}\text { Mandar-phang, } \\
\text { Kantab }\end{array}$ & $\begin{array}{l}\text { Birishiri, } \\
\text { Netrokona; } \\
\text { Chonia, Tangail }\end{array}$ & $\begin{array}{l}\text { Stem and shoot are used in "Ramachittya" } \\
\text { (funeral procession). Stem-gum is used for } \\
\text { dysentery. }\end{array}$ \\
\hline 48. & Euphorbia antiquorum L. & Euphorbiaceae & A-rong-jora & $\begin{array}{l}\text { Menkifanda, } \\
\text { Netrokona }\end{array}$ & $\begin{array}{l}\text { Whole plant paste is used in treating fractured } \\
\text { bones. }\end{array}$ \\
\hline 49. & Euphorbia hirta L. & Euphorbiaceae & Khatri-bi-phang & $\begin{array}{l}\text { Hagurakuri, } \\
\text { Tangail }\end{array}$ & Leaf paste is used in skin diseases. \\
\hline 50. & Ficus benghalensis L. & Moraceae & Prup-phang & $\begin{array}{l}\text { Menkifanda, } \\
\text { Netrokona }\end{array}$ & $\begin{array}{l}\text { Dried aerial root burnt and the "Khar" (ash) is } \\
\text { used in vegetable preparation instead of oil. This } \\
\text { tree has a sacred value also. }\end{array}$ \\
\hline 51. & $\begin{array}{l}\text { Ficus racemosa L. (Syn. F. } \\
\text { glomerata Roxb.) }\end{array}$ & Moraceae & $\begin{array}{l}\text { Koudra-phang, } \\
\text { Twe-aek }\end{array}$ & $\begin{array}{l}\text { Sagordighi, } \\
\text { Netrokona }\end{array}$ & $\begin{array}{l}\text { Seed paste is used in piles. Young twig juice is } \\
\text { used for diabetes. }\end{array}$ \\
\hline 52. & Ficus religiosa $\mathrm{L}$ & Moraceae & Gitingbel & $\begin{array}{l}\text { Telungia, } \\
\text { Netrokona }\end{array}$ & $\begin{array}{l}\text { Dried aerial root burnt and the "Khar" (ash) is } \\
\text { used in vegetable preparation in place of oil. This } \\
\text { tree is sacred. }\end{array}$ \\
\hline 53. & $\begin{array}{l}\text { Flacourtia jangomas (Lour.) } \\
\text { Raeusch. (Syn. F. cataphracta } \\
\text { Roxb. ex Willd.) }\end{array}$ & Flacourtiaceae & $\begin{array}{l}\text { Che-marang, } \\
\text { Dari-chick }\end{array}$ & $\begin{array}{l}\text { Menkifanda, } \\
\text { Netrokona }\end{array}$ & $\begin{array}{l}\text { Paste of } 7 \text { young twigs of "Che-marang" and } \\
\text { "Nailla" (Corchorus copsularis) seeds is used in } \\
\text { infertility of women after four days of } \\
\text { menstruation. }\end{array}$ \\
\hline 54. & $\begin{array}{l}\text { Flemingia semialata Roxb. ex. } \\
\text { Ait. (Syn. F. congesta Roxb. ex. } \\
\text { Ait.) }\end{array}$ & Papilionaceae & Do-fatchi & $\begin{array}{l}\text { Thanarbaid, } \\
\text { Tangail }\end{array}$ & $\begin{array}{l}\text { Root and young twig juice is used for gastric } \\
\text { problem. }\end{array}$ \\
\hline 55. & Ganoderma sp. & Ganodermataceae & $\begin{array}{l}\text { Kanchata, } \\
\text { Kanchara }\end{array}$ & $\begin{array}{l}\text { Sagordighi, } \\
\text { Netrokona }\end{array}$ & $\begin{array}{l}\text { Sun-dried fruit body burnt and the ash is soaked } \\
\text { in water and used for children's "Dudsari" } \\
\text { (diarrhoea of children after breastfeeding). }\end{array}$ \\
\hline
\end{tabular}




\section{Table 1. (Contd.)}

\begin{tabular}{|c|c|c|c|c|c|}
\hline $\begin{array}{l}\text { Sl. } \\
\text { No. }\end{array}$ & Scientific name & Family & Mandi name & $\begin{array}{l}\text { Location } \\
\text { (Village, District) }\end{array}$ & Use \\
\hline 56. & Gmelina arborea Roxb. & Verbenaceae & Gambari-phang & Chonia, Tangail & $\begin{array}{l}\text { Timber is used for making the socio-religious } \\
\text { musical instrument "Dama", and also to make } \\
\text { "K'ma/Khima" (monument for dead person). }\end{array}$ \\
\hline 57. & $\begin{array}{l}\text { Gossypium arboreum L. (Syn. G. } \\
\text { harbaceum L.) }\end{array}$ & Malvaceae & Chon-na-khel & $\begin{array}{l}\text { Achkipara, } \\
\text { Mymensingh; } \\
\text { Boheratoli, } \\
\text { Netrokona }\end{array}$ & $\begin{array}{l}\text { Oil extracted from the seeds is used in lamps. The } \\
\text { plant is the main source of cotton fibre for Mandi } \\
\text { clothes. }\end{array}$ \\
\hline 58. & Hibiscus sabdariffa L. & Malvaceae & Menda-guru & Pirgacha, Tangail & Young twig and fruit are used as vegetables. \\
\hline 59. & Hyptis suaveolens (L.) Poir. & Lamiaceae & Do-ju & $\begin{array}{l}\text { Menkifanda, } \\
\text { Netrokona }\end{array}$ & $\begin{array}{l}\text { Sun-dried seeds are soaked in water for } 12 \text { hrs. } \\
\text { The mucilaginous extract is used for constipation. }\end{array}$ \\
\hline 60. & $\begin{array}{l}\text { Imperata cylindrica (L.) P. } \\
\text { Beauv }\end{array}$ & Poaceae & Gong-chamri & $\begin{array}{l}\text { Rajai, } \\
\text { Sunamganj }\end{array}$ & $\begin{array}{l}\text { 'Sanksarek Mandi' (animist) believes that, creator } \\
\text { "Bagoba-borombi" first created this plant in this } \\
\text { world. This plant is the main thatching material in } \\
\text { the areas. }\end{array}$ \\
\hline 61. & Jatropha gossipifolia L. & Euphorbiaceae & $\begin{array}{l}\text { Krendagichha, } \\
\text { Balgechak }\end{array}$ & $\begin{array}{l}\text { Sagordighi, } \\
\text { Netrokona }\end{array}$ & $\begin{array}{l}\text { Paste made of young twig of "Krendagichha" and } \\
\text { Tamarindus indica seed is used to relieve piles } \\
\text { pain. }\end{array}$ \\
\hline 62. & Justicia gendarusa L. & Acanthaceae & Dojagappi & $\begin{array}{l}\text { Menkifanda, } \\
\text { Netrokona }\end{array}$ & $\begin{array}{l}\text { Paste made of "Dojagappi" leaf and "Nisinda" } \\
\text { (Vitex negundo) leaf is used in the wounds. }\end{array}$ \\
\hline 63. & $\begin{array}{l}\text { Kaempferia pulchra (Syn. } K . \\
\text { marginata) }\end{array}$ & Zingiberaceae & Wak-fatra & $\begin{array}{l}\text { Sagordighi, } \\
\text { Netrokona }\end{array}$ & $\begin{array}{l}\text { Tuber paste is used in the treatment of pheumonia } \\
\text { and bronchial complaints. }\end{array}$ \\
\hline 64. & Lagenaria siceria Standl. & Cucurbitaceae & Fong & Chonia, Tangail & $\begin{array}{l}\text { Sun-dried fruit shell is used as "Fong-reng", } \\
\text { "Fong-shen" and "Fong-saljong" (utensils used } \\
\text { for drink traditional liquor "Chu" and sometimes } \\
\text { women conserve different types of crop seeds in } \\
\text { this natural shell-pot). }\end{array}$ \\
\hline
\end{tabular}




\section{Table 1. (Contd.)}

\begin{tabular}{|c|c|c|c|c|c|}
\hline $\begin{array}{l}\text { Sl. } \\
\text { No. }\end{array}$ & Scientific name & Family & Mandi name & $\begin{array}{l}\text { Location } \\
\text { (Village, District) }\end{array}$ & Use \\
\hline 65. & $\begin{array}{l}\text { Lannea coromandelica (Houtt.) } \\
\text { Merr. (Syn. L. grandis (Dennst.) } \\
\text { Eng.) }\end{array}$ & Anacardiaceae & Gika-phang & $\begin{array}{l}\text { Utrail, Netro- } \\
\text { kona; Bheduria } \\
\text { \& Thanarbaid, } \\
\text { Tangail }\end{array}$ & $\begin{array}{l}\text { Green fruit is used in chicken pox. Decoction of } \\
\text { stem-bark is used as red dye. Stem and shoot are } \\
\text { used in "Ramachittya" (funeral procession). }\end{array}$ \\
\hline 66. & $\begin{array}{l}\text { Lasia spinosa (L.) Thw. (Syn. L. } \\
\text { heterophylla Schoott., } \\
\text { L. aculeata Lour.) }\end{array}$ & Araceae & $\begin{array}{l}\text { Chongi-bret, } \\
\text { Gong-mentre }\end{array}$ & $\begin{array}{l}\text { Rajai, } \\
\text { Sunamganj }\end{array}$ & Used as vegetables. \\
\hline 67. & Leea macrophylla Roxb. & Leeaceae & $\begin{array}{l}\text { Udum-sam, A- } \\
\text { thi-nachel }\end{array}$ & $\begin{array}{l}\text { Chonia \& } \\
\text { Jolchotra, } \\
\text { Tangail }\end{array}$ & $\begin{array}{l}\text { Leaf and root cut into small pieces and soaked in } \\
\text { water for } 4-5 \text { hrs. The mucilaginous extract is } \\
\text { used for increasing sperm count. Leaf paste is } \\
\text { used for treating fractured bones. }\end{array}$ \\
\hline 68. & $\begin{array}{l}\text { Leucas indica (L.) R. Br. ex } \\
\text { Vatke }\end{array}$ & Lamiaceae & $\begin{array}{l}\text { Domkolos, } \\
\text { Korponath }\end{array}$ & $\begin{array}{l}\text { Menkifanda, } \\
\text { Netrokona }\end{array}$ & $\begin{array}{l}\text { Inflorescence and root paste is used in insect and } \\
\text { snake bites. }\end{array}$ \\
\hline 69. & Lygodium sp. & Lygodiaceae & Royatoop & $\begin{array}{l}\text { Menkifanda, } \\
\text { Netrokona }\end{array}$ & $\begin{array}{l}\text { Rhizome stalk paste is mixed with sugar and used } \\
\text { in gonorrhoea. }\end{array}$ \\
\hline 70. & Mangifera indica L. & Anacardiaceae & Thegachu & $\begin{array}{l}\text { Birishiri, } \\
\text { Netrokona; } \\
\text { Narayantala, } \\
\text { Sunamganj }\end{array}$ & $\begin{array}{l}\text { Fresh stem-bark juice is mixed with sugar and is } \\
\text { used for dysentery. Leaf is used in the ritual } \\
\text { "Reen-chottya". Timber is used to make } \\
\text { "K'ma/Khima" (monument for dead person). }\end{array}$ \\
\hline 71. & Manihot esculenta Crantz. & Euphorbiaceae & Tha-bol-chu & $\begin{array}{l}\text { Sagordighi, } \\
\text { Netrokona; } \\
\text { Thanarbaid, } \\
\text { Tangail }\end{array}$ & $\begin{array}{l}\text { One of the main crops in Mandi areas. Tuber } \\
\text { paste is used in preparation of fermenting medium } \\
\text { "Chumanti" (traditional yeast cake) for traditional } \\
\text { liquor "Chu". Dried leaf and stem are burnt and } \\
\text { the ash ("Khar") is used in cooking instead of oil. }\end{array}$ \\
\hline 72. & Marsilea quadrifoliata L. & Marsileaceae & $\begin{array}{l}\text { Mikhampret, } \\
\text { Sampret }\end{array}$ & $\begin{array}{l}\text { Menkifanda, } \\
\text { Netrokona }\end{array}$ & $\begin{array}{l}\text { Whole plant paste is soaked in hot water and is } \\
\text { used for treating toothache. }\end{array}$ \\
\hline
\end{tabular}




\section{Table 1. (Contd.)}

\begin{tabular}{|c|c|c|c|c|c|}
\hline $\begin{array}{l}\text { Sl. } \\
\text { No. }\end{array}$ & Scientific name & Family & Mandi name & $\begin{array}{l}\text { Location } \\
\text { (Village, District) }\end{array}$ & Use \\
\hline 73. & Melastoma malabathrica $\mathrm{L}$ & Melastomaceae & Kakku-phang & $\begin{array}{l}\text { Rajai, } \\
\text { Sunamganj }\end{array}$ & Stem is used as toothbrush. \\
\hline 74. & $\begin{array}{l}\text { Microcos paniculata L. ex W. \& } \\
\text { A. (Syn. Grewia microcos Wall. } \\
\text { ex Mast.) }\end{array}$ & Tiliaceae & $\begin{array}{l}\text { Dhamsi-bret, } \\
\text { Datoi-phang }\end{array}$ & $\begin{array}{l}\text { Rajai, } \\
\text { Sunamganj }\end{array}$ & Ripe fruits are edible. \\
\hline 75. & $\begin{array}{l}\text { Mikania cordata (Burm. f.) } \\
\text { Roxb. }\end{array}$ & Asteraceae & Athisaheph & Chonia, Tangail & $\begin{array}{l}\text { Young leaf are fried in oil and eaten by persons } \\
\text { suffering from gastric pain. }\end{array}$ \\
\hline 76. & Mimosa pudica L. & Mimosaceae & $\begin{array}{l}\text { Ambi-michhum, } \\
\text { Sammachup }\end{array}$ & $\begin{array}{l}\text { Baragup, } \\
\text { Sunamganj }\end{array}$ & $\begin{array}{l}\text { Dried root tied to the arm in the treatment of } \\
\text { women's infertility. Root paste is applied locally } \\
\text { for alleviating inflammation of breast. }\end{array}$ \\
\hline 77. & $\begin{array}{l}\text { Moringa oleifera Lamk. (Syn. } M \text {. } \\
\text { peterygosperma Gaertn.) }\end{array}$ & Moringaceae & Sajna-phang & $\begin{array}{l}\text { Sainnanaari, } \\
\text { Tangail }\end{array}$ & $\begin{array}{l}\text { Fresh stem bark paste is used in the treatment of } \\
\text { fractured bones. }\end{array}$ \\
\hline 78. & Musa ornata Roxb & Musaceae & $\begin{array}{l}\text { Thirik-phang, } \\
\text { Echim-chimri }\end{array}$ & $\begin{array}{l}\text { Bhabanipur \& } \\
\text { Utrail, } \\
\text { Netrokona; } \\
\text { Khazai, Tangail }\end{array}$ & $\begin{array}{l}\text { "Sanksarek Mandi" (animist) believes that, the } \\
\text { creator "Bagoba-borombi" first created this plant } \\
\text { in this world. Dried inflorescence axis with } \\
\text { sheaths is burnt and the "Khar" (ash) is used in } \\
\text { vegetable preparation instead of oil. Pseudostem } \\
\text { is used in the religious worship "Bidaw-E-Chibal" } \\
\text { for edema during and after pregnancy of women. } \\
\text { Whole plant is used in the religious worship } \\
\text { "Ronsri-meddi" for good health and wealth. }\end{array}$ \\
\hline 79. & Nymphaea nouchali Burm. f. & Nymphaeaceae & $\begin{array}{l}\text { Bibalchak, } \\
\text { Gechhak-afluk }\end{array}$ & $\begin{array}{l}\text { Sagordighi, } \\
\text { Netrokona }\end{array}$ & $\begin{array}{l}\text { Rhizome paste is used to treat menstruation } \\
\text { problem. }\end{array}$ \\
\hline 80. & Opuntia dilenii Haw. & Cactaceae & Narpanda-siju & $\begin{array}{l}\text { Sagordighi, } \\
\text { Netrokona }\end{array}$ & Stem latex is used in eye diseases of cattle. \\
\hline
\end{tabular}




\section{Table 1. (Contd.)}

\begin{tabular}{|c|c|c|c|c|c|}
\hline $\begin{array}{l}\text { Sl. } \\
\text { No. }\end{array}$ & Scientific name & Family & Mandi name & $\begin{array}{l}\text { Location } \\
\text { (Village, District) }\end{array}$ & Use \\
\hline 81. & Peperomia pellucida Kunth. & Piperaceae & $\begin{array}{l}\text { Samol-phang, } \\
\text { Phanmachii }\end{array}$ & Taltala, Tangail & $\begin{array}{l}\text { Whole plant juice is used in wounds. Sun-dried } \\
\text { plant pieces is tied with a piece of black thread to } \\
\text { the hip of women in edema. }\end{array}$ \\
\hline 82. & Persicaria lanatum Roxb. & Polygonaceae & Hagra & $\begin{array}{l}\text { Menkifanda, } \\
\text { Netrokona }\end{array}$ & $\begin{array}{l}\text { Root mixed with "Gomenda" (Cucurbita maxima) } \\
\text { fruit-bark and table salt and made into paste. This } \\
\text { paste is also used to relieve finger pain. }\end{array}$ \\
\hline 83. & $\begin{array}{l}\text { Phyllanthus emblica L. (Syn. } \\
\text { Emblica officinalis Gaertn. ) }\end{array}$ & Euphorbiaceae & Ambori-phang & Chonia, Tangail & Fruits are edible. \\
\hline 84. & Physalis minima $\mathrm{L}$. & Solanaceae & Ambichok & $\begin{array}{l}\text { Sagordighi, } \\
\text { Netrokona }\end{array}$ & $\begin{array}{l}\text { Leaf juice is mixed with "Ak-kharu" (Benincasa } \\
\text { hispida) seed juice and is used locally in eye } \\
\text { diseases. }\end{array}$ \\
\hline 85. & $\begin{array}{l}\text { Poinciana pulcherrima L. (Syn. } \\
\text { Caesalpinia pulcherrima } \\
\text { Swartz.) }\end{array}$ & Caesalpiniaceae & Rummoth-phang & $\begin{array}{l}\text { Birishiri, } \\
\text { Netrokona }\end{array}$ & $\begin{array}{l}\text { Young twig juice is used in abortion at } 3 \text { months } \\
\text { of pregnancy. Fresh flower juice is used for cough } \\
\text { and cold. }\end{array}$ \\
\hline 86. & $\begin{array}{l}\text { Polycarpon prostratum Forsk. } \\
\text { (Syn. P. loeflineae Benth. et } \\
\text { Hook. f.) }\end{array}$ & Caryophylaceae & $\begin{array}{l}\text { Beng-bong- } \\
\text { jathong }\end{array}$ & Chonia, Tangail & Leaves are used as vegetables. \\
\hline 87. & Punica granatum L. & Punicaceae & Dalim-phang & $\begin{array}{l}\text { Boheratoli \& } \\
\text { Menkifanda, } \\
\text { Netrokona }\end{array}$ & $\begin{array}{l}\text { Young twig paste is used for ascar of domestic } \\
\text { pig. Decoction of root bark with table salt for } \\
\text { expelling human worms. }\end{array}$ \\
\hline 88. & Rauvolfia serpentina Benth. & Apocynaceae & Do-grek-mi & $\begin{array}{l}\text { Thanarbaid, } \\
\text { Tangail }\end{array}$ & $\begin{array}{l}\text { Root and leaf paste is made into pill, sun-dried } \\
\text { and used in malarial fever. }\end{array}$ \\
\hline 89. & Saccharum spontaneum L. & Poaceae & Kash & Utrail, Netrokona & Stem is used in worship of "Bagoba-borombi". \\
\hline 90. & Scoparia dulcis $\mathrm{L}$ & Scrophulariaceae & Sam-khucuk & Khazai, Tangail & Young twig and leaf are used as vegetables. \\
\hline 91. & Semecarpus anacardium L. f. & Anacardiaceae & $\begin{array}{l}\text { Baula, Bhewla- } \\
\text { phang }\end{array}$ & $\begin{array}{l}\text { Pirgacha, } \\
\text { Tangail }\end{array}$ & Seed kernel is edible. \\
\hline
\end{tabular}




\section{Table 1. (Contd.)}

\begin{tabular}{|c|c|c|c|c|c|}
\hline $\begin{array}{l}\text { Sl. } \\
\text { No. }\end{array}$ & Scientific name & Family & Mandi name & $\begin{array}{l}\text { Location } \\
\text { (Village, District) }\end{array}$ & Use \\
\hline 92. & Shorea robusta Gaertn. & Dipterocarpaceae & $\begin{array}{l}\text { Bolsal, Bor- } \\
\text { shalphang }\end{array}$ & $\begin{array}{l}\text { Chonia, Gaira, } \\
\text { Khazai \& } \\
\text { Thanarbaid, } \\
\text { Tangail }\end{array}$ & $\begin{array}{l}\text { Stem-bark juice is used to treat ulceration of } \\
\text { mouth. Stem resin is used as insect/mosquito } \\
\text { repellent. Stem-bark is used to make red dye. } \\
\text { Seed can be eaten after roasted. Timber is used to } \\
\text { make "K'ma/Khima" (monument for dead } \\
\text { person). }\end{array}$ \\
\hline 93. & $\begin{array}{l}\text { Sida cordata (Burm.f.) Borssum. } \\
\text { (Syn. S. veronicaefolia Lam.) }\end{array}$ & Malvaceae & Sam-fathal & $\begin{array}{l}\text { Menkifanda, } \\
\text { Netrokona }\end{array}$ & $\begin{array}{l}\text { Paste made of "Sam-fathal" root and "Gokkared" } \\
\text { (Costus speciosus) rhizome is used in gonorrhoea. }\end{array}$ \\
\hline 94. & Sida sp. & Malvaceae & Sam-fathal & $\begin{array}{l}\text { Birishiri, } \\
\text { Netrokona }\end{array}$ & $\begin{array}{l}\text { Whole plant paste is used for rheumatic pain. } \\
\text { Decoction of seed is used to increase sperm } \\
\text { count. }\end{array}$ \\
\hline 95. & $\begin{array}{l}\text { Smilax zeylanica L. (Syn. S. } \\
\text { macrophylla Roxb.) }\end{array}$ & Smilacaceae & Sam-refu & Chonia, Tangail & $\begin{array}{l}\text { Decoction of leaf mixed in warm water and is } \\
\text { used in bath for children with "Pesera" (measles). }\end{array}$ \\
\hline 96. & Solanum melongena Wall. & Solanaceae & Misinachole & $\begin{array}{l}\text { Birishiri, } \\
\text { Netrokona; } \\
\text { Narayantala, } \\
\text { Sunamganj }\end{array}$ & $\begin{array}{l}\text { Leaf juice is mixed with sugar and is used in } \\
\text { dysentery. Leaf juice is mixed with mother's milk } \\
\text { and is used in diarrhoea in infants. }\end{array}$ \\
\hline 97. & Solanum xanthocarpum L. & Solanaceae & $\begin{array}{l}\text { Khuka, } \\
\text { Bekaigota }\end{array}$ & $\begin{array}{l}\text { Bhabanipur } \\
\text { (North) \& } \\
\text { Lengoora, } \\
\text { Netrokona }\end{array}$ & $\begin{array}{l}\text { Dried fruit is used in preparation of "Chumanti" } \\
\text { (preparation medium of traditional liqour "Chu"). } \\
\text { Fruits fried in oil and is used for scabies. }\end{array}$ \\
\hline 98. & Sterblus asper Lour. & Moraceae & Shawla & $\begin{array}{l}\text { Songra, } \\
\text { Mymensingh; } \\
\text { Menkifanda, } \\
\text { Netrokona }\end{array}$ & $\begin{array}{l}\text { It is locally believed that, evil spirit live in this } \\
\text { tree. So it is not planted in homesteads. Ripe } \\
\text { fruits are eaten by children. Paste of root-bark is } \\
\text { used in dysentery. }\end{array}$ \\
\hline
\end{tabular}




\section{Table 1. (Contd.)}

\begin{tabular}{|c|c|c|c|c|c|}
\hline $\begin{array}{l}\text { Sl. } \\
\text { No. }\end{array}$ & Scientific name & Family & Mandi name & $\begin{array}{l}\text { Location } \\
\text { (Village, District) }\end{array}$ & Use \\
\hline 99. & Tamarindus indica L. & Caesalpiniaceae & $\begin{array}{l}\text { Amlichuka, } \\
\text { Tintili-phang }\end{array}$ & $\begin{array}{l}\text { Menkifanda, } \\
\text { Netrokona }\end{array}$ & $\begin{array}{l}\text { Decoction of ripe fruit pulp is used for dyspepsia } \\
\text { of domestic pig. }\end{array}$ \\
\hline 100. & $\begin{array}{l}\text { Thysanolaena maxima (Roxb.) } \\
\text { Kuntze. (Syn. Agrostis maxima } \\
\text { Roxb.) }\end{array}$ & Poaceae & Sarla-phang & $\begin{array}{l}\text { Rajai, } \\
\text { Sunamganj }\end{array}$ & Used for making broom and thatching material. \\
\hline 101. & $\begin{array}{l}\text { Trichosanthes bracteata (Lamk.) } \\
\text { Voigt. (Syn. Modecca bracteata } \\
\text { Lamk.) }\end{array}$ & Cucurbitaceae & Mamalaru & $\begin{array}{l}\text { Sainnamari, } \\
\text { Tangail }\end{array}$ & $\begin{array}{l}\text { Dried fruit pulp soaked in water and the extract is } \\
\text { used to alleviate liver complaints. }\end{array}$ \\
\hline 102. & Utricularia flexuosa Vahl. & Lentibulariaceae & Joler-satmul & $\begin{array}{l}\text { Sagordighi, } \\
\text { Netrokona }\end{array}$ & Dried plant is used for menstruation problem. \\
\hline 103. & Vetiveria zizanioides (L.) Nash & Poaceae & Bimachuba & $\begin{array}{l}\text { Sagordighi, } \\
\text { Netrokona }\end{array}$ & $\begin{array}{l}\text { Paste of } 7 \text { young leaf-twig is used in "Dudsari" } \\
\text { (diarrhoea of children after breastfeeding). }\end{array}$ \\
\hline 104. & $\begin{array}{l}\text { Vigna sinensis Endl. ex Hassk. } \\
\text { (Syn. V. catjang var. sinensis } \\
\text { Prain.) }\end{array}$ & Papilionaceae & Kharek & $\begin{array}{l}\text { Hagurakuri, } \\
\text { Tangail }\end{array}$ & $\begin{array}{l}\text { This plant is the clan totem of "Nokrek" clan in } \\
\text { Mandi society. }\end{array}$ \\
\hline 105. & Vitis latifolia Roxb. & Vitaceae & Bon angur & $\begin{array}{l}\text { Pirgacha, } \\
\text { Tangail }\end{array}$ & Young leaf and stem are used as vegetables. \\
\hline 106. & $\begin{array}{l}\text { Wedelia chinensis (Osb.) Merrill. } \\
\text { (Syn. W. calendulaceae Less.) }\end{array}$ & Capparidaceae & Baw-batasi & $\begin{array}{l}\text { Sagordighi, } \\
\text { Netrokona }\end{array}$ & $\begin{array}{l}\text { Leaf juice is used for children in any physical } \\
\text { change caused by supernatural power called } \\
\text { "Kharap batas laga". }\end{array}$ \\
\hline 107. & Withania somnifera (L.) Dunal. & Solanaceae & Achothra & $\begin{array}{l}\text { Thanarbaid, } \\
\text { Tangail }\end{array}$ & $\begin{array}{l}\text { Root juice is mixed with lime water and used in } \\
\text { diarrhoea. }\end{array}$ \\
\hline 108. & $\begin{array}{l}\text { Zanthoxylum budrunga (Roxb.) } \\
\text { DC }\end{array}$ & Rutaceae & $\begin{array}{l}\text { Kankoi, } \\
\text { Khankoi }\end{array}$ & Khazai, Tangail & Young twig and leaf are used as vegetables. \\
\hline 109. & Zanthoxylum rhetsa (Roxb.) DC. & Rutaceae & Sumu-cheng & Chonia, Tangail & $\begin{array}{l}\text { Timber is used for making the religious musical } \\
\text { instrument "Ambangii". }\end{array}$ \\
\hline
\end{tabular}


- Rights of every ethnic group (including the Intellectual Property Rights) to use traditionally used plant species for their own usage is to be ensured under the Convention on Biological Diversity (CBD).

- Active participation of the ethnic people in making decisions and formulating laws and state policies for ethnic people is to be ensured.

- All the medicinal, edible, economic and other threatened plants mentioned in this investigation can only be conserved through traditional knowledge and culture, which stated community-based conservation. All plant species are to be protected in situ with the co-operation of the ethnic and local people and of the Forest Department of the country.

\section{Acknowledgements}

We wish to express our sincere appreciation and the deepest sense of gratitude to Ajit Ritchil (Menkifanda), Tokkia Rema (Utrail), Kanu Ritchil (Monsapara), Prhalhad Chandra Jambil, R.M.P. (Boheratili), Robin Marak (Sagardigi), Mitali Ruram and Jotindra Manda (Birishiri Mandi Bazar), Shamim Ritchil (Bhobanipur), Pronat Rema (Taltola-Thanarbaid), Uttam Ritchil and Srijon Sangma (Tribal Cultural Academy, Birishiri), Noyan Sangma (Rajai), Porag Ritchil (Haluaghat), Monindranath Marak (Birishiri), Shijen Marak, Shibram Nokrek and Neta Nokrek (Hagurakuri), Janin Nokrek and Shyamchoron Rema (Sainnyamari), Jonik Nokrek, Soheen Mree, Bijonty Mree and Anita Mree (Chonia), Jerome Hagidok (Bheduria), Ajoy A. Mree, Babul D. Nokrek and Somola Marak (Gachabari), Uzine Nokrek (Gaira), and the people of Mandi communities in the local areas for their cordial inspiration, sharing, cooperation and guidance. Thanks are also due to the Bangladesh National Herbarium and the Department of Botany, Jahangirnagar University for botanical identification and academic suggestions.

\section{References}

Alam, M.K. 1992. Medicinal ethnobotany of the Marma tribe of Bangladesh. Economic Botany 46(3): 330335.

Alam, M.K., Choudhury, J. and Hassan, M.A. 1996. Some folk formularies from Bangladesh. Bangladesh J. Life Sci. 8(1): 49-63.

Hassan, M.A. and Khan, M.S. 1986. Ethnobotanical records in Bangladesh-1 : plants used for healing fractured bones. Jour. Asiatic Soc. Bangladesh. (Sc.). 12(1\&2): 33-39.

Khan, M.S. 1998. Prospects of ethnobotany and ethnobotanical research in Bangladesh. In: Banik, R.L., Alam, M.K., Pei, S.J. and Rastogi, A. (eds.), Applied Ethnobotany. Bangladesh Forest Research Institute, Chittagong, Bangladesh, pp. 24-27.

Khan, M.S., Hassan, M.A. and Uddin, M.Z. 2002. Ethnobotanical survey in Rema-Kalenga wildlife sanctuary (Habigonj) in Bangladesh. Bangladesh J. Plant Taxon. 9(1): 51-60.

Mia, M.M.K. and Huq, A.M. 1988. A preliminary ethnobotanical survey in the Jointopur, Tamabil and Jaflong (Jointapur Upazilla), Sylhet. In: Khan, M.S. (ed.), Bull. of Bangladesh National Herbarium, No. 3. Bangladesh National Herbarium, Dhaka, pp. 1-10. 
Partha, P. 2002. Ethnobotanical investigation of the ethnic communities living in greater Dhaka and Sylhet Divisions of Bangladesh. M.Sc. Thesis, Department of Botany, Jahangirnagar University, pp. 390. (unpublished)

Partha, P. and Hossain, A.B.M.E. 2002. Ethnoconservational practices by 14 ethnic communities in Bangladesh. In: Bangladesh Environment 2002, 1: 523-530. Bangladesh Poribesh Andolon, Dhaka.

Rao, M.K.V. and Shampru, R. 1997. Some plants in the life of the Garos of Meghalaya. In: Jain, S.K. (ed.), Contribution to Indian Ethnobotany. Scientific Publishers, Jodhpur, India, pp. 179-186.

Rao, R.R. 1981. Ethnobotany of Meghalaya: Medicinal plants used by Khasi and Garo Tribes. Economic Botany 35(1): 4-9.

Uddin, M.Z., Khan, M.S. and Hassan, M.A. 2001. Ethnomedical plant records of Kalenga forest Range (Habiganj), Bangladesh for malaria, jaundice, diarrhoea and dysentry. Bangladesh J. Plant. Taxon. 8(1): 101-104.

Yusuf, M., Wahab, M.A., Chowdhury, J.U. and Begum, J. 2006. Ethno-medico-botanical knowledge from Kaukhali proper and Betbunia of Rangamati District. Bangladesh J. Plant Taxon. 13(1): 55-61.

(Manuscript received on 13 May 2007; revised on 9 November 2007) 